\title{
Developing a Higher Order Thinking Skills Module for Weak ESL Learners
}

\author{
Charanjit Kaur Swaran Singh ${ }^{1}$, Rhashvinder Kaur Ambar Singh ${ }^{1}$, Tarsame Singh Masa Singh ${ }^{2}$, \\ Nor Azmi Mostafa ${ }^{1} \&$ Tunku Mohani Tunku Mohtar ${ }^{1}$ \\ 1 English Language and Literature Department, Faculty of Languages and Communication, Universiti \\ Pendidikan Sultan Idris, Malaysia \\ ${ }^{2}$ English Language Unit, Language Department, Institute of Teacher Education, Tuanki Bainun Campus, \\ Malaysia \\ Correspondence: Charanjit Kaur Swaran Singh, English Language and Literature Department, Faculty of \\ Languages and Communication, Universiti Pendidikan Sultan Idris, Malaysia. Tel: 60-126-635-068. E-mail: \\ charanjit@fbk.upsi.edu.my
}

Received: April 9, 2018 Accepted: June 11, 2018 Online Published: June 13, 2018

doi: 10.5539/elt.v11n7p86 URL: http://doi.org/10.5539/elt.v11n7p86

\begin{abstract}
The problem of mastering English does not involve students alone. The English language teachers, policy makers and curriculum developers are also affected. Thus, teachers have resorted to using higher order thinking skills (HOT) as a means to teach writing to weak ESL learners. The study aimed at developing and validating a higher order thinking skills module for teaching writing to weak ESL learners. It employed a qualitative research paradigm using documents analysis, interviews, observations and validation form. It was conducted in two phases. The first phase was completed with needs analysis specifically identifying problems teachers faced in teaching writing using higher order thinking skills in six selected secondary schools. The ADDIE model approach was used by the ESL teachers and experts in HOTs to create the module content. In the second phase, the teachers were observed ten times to investigate the effectiveness of using the HOTs module developed for teaching writing. The findings revealed that the HOTs module served as a guideline for the teachers in applying and integrating thinking skills in the process of teaching writing. These findings were used to guide decisions on implementing the appropriate teaching pedagogy to apply HOTS for teaching writing.
\end{abstract}

Keywords: higher order thinking skills, module for teaching writing, ESL teachers, ESL learners

\section{Introduction}

Teachers face a number of problems when conducting writing lessons (Rajendran, 1999). One of the most common problems is implementing higher order thinking skills questions when teaching writing. Teachers have problem in finding the right time to implement higher order thinking skills questions in teaching writing. Teaching to write in a second language is a complex process that takes time, effort and practice. Even worse, writing is usually taught in isolation from other language skills. Students have to go through a complex and routine processes of writing and this has made writing a monotonous and boring subject especially for weak learners.

Based on the preliminary Report of the Malaysia Education Blueprint 2013-2025, most English lessons in schools do not highlight constructive thinking as most classrooms are teacher based and focused on the lower order thinking skills which are recalling or stating information. Teachers are unaware of how to teach thinking skills to a number of students at the same time. Based on Tajularipin et al. (2017), it is difficult to teach HOTS to a big class of students compared to a small class. This phenomenon occurs when teachers are unaware of how to tap and tackle students' thinking skills. Tajularipin et al. (2017) suggest that teachers first need to understand what HOTS entail. Only then are they able to apply this knowledge in teaching HOTS to the students especially when teaching the productive skills.

Their years of teaching experience have significantly influenced teachers' perceptions of their own knowledge and skills. Many factors such as teachers' own orientation toward teaching, curricular requirements and myths about teaching writing inhibit the teaching of higher order thinking skills (Hashim, 2003). A recent study by Siti 
(2016) that evaluated teachers' perspective revealed that teachers believe they did not undergo enough training on integrating HOTS in their lessons. Using HOTS in the classroom also requires more than giving students higher order thinking questions; rather, students must be taught how to make thinking visible and this can be done with teacher guidance (Siti, 2016). Thus, a study is needed to increase focus on investigating the higher order thinking skills (HOTS) for ESL teachers specifically in writing.

It is necessary to conduct research to develop an instrument that can be used for measuring the students' HOTS (Tanujaya 2016). The teachers are unable to be creative and employ new techniques to teach writing and implementing higher order thinking skills into teaching writing becomes more difficult. This is proven as according to Rajendran (1999), teachers requested new materials to enable them to teach better by using higher order thinking skills. Teachers are already considering adopting new types of questions with more analytical and creative values to prevent students from expressing their insecurity and lack of confidence in completing tasks.

Therefore, to assist the teachers in teaching HOTS, the HOTS writing module was developed. To bridge the gap in finding good materials for teaching HOTS, the researchers developed a 20-question writing module complete with lesson plans and answer schemes. This module was prepared using the curriculum standard specification as a guideline. It followed all the chapters in the Form Two syllabus. The questions in the module are prepared to trigger students to use Higher Order Thinking Skills when writing. These questions will either allow teachers to do higher order thinking skills questioning or carry out higher order thinking skills activities suited for Form Two students. The module will also assist the teachers in teaching writing as it provides guidelines for them to implement HOTS in their lessons. Therefore there is a need to develop a module that incorporates HOTS for teaching writing to assist teachers to better understand HOTS implementation.

\section{Theoretical and Conceptual Framework Used in the Module Development}

The theoretical framework constructed depicts the relationship of using four cognitive theories namely constructivist theory, Gestalt theory, information processing theory and schema theory in developing the module. It maps out the theoretical framework that underlies the relationships between the variables in the research that are the higher order thinking skills used in the module. These theories provide better understanding in investigating ESL learners' schemata and their higher order thinking skills during ESL learners' productive medium which is writing (refer to Figure 1).

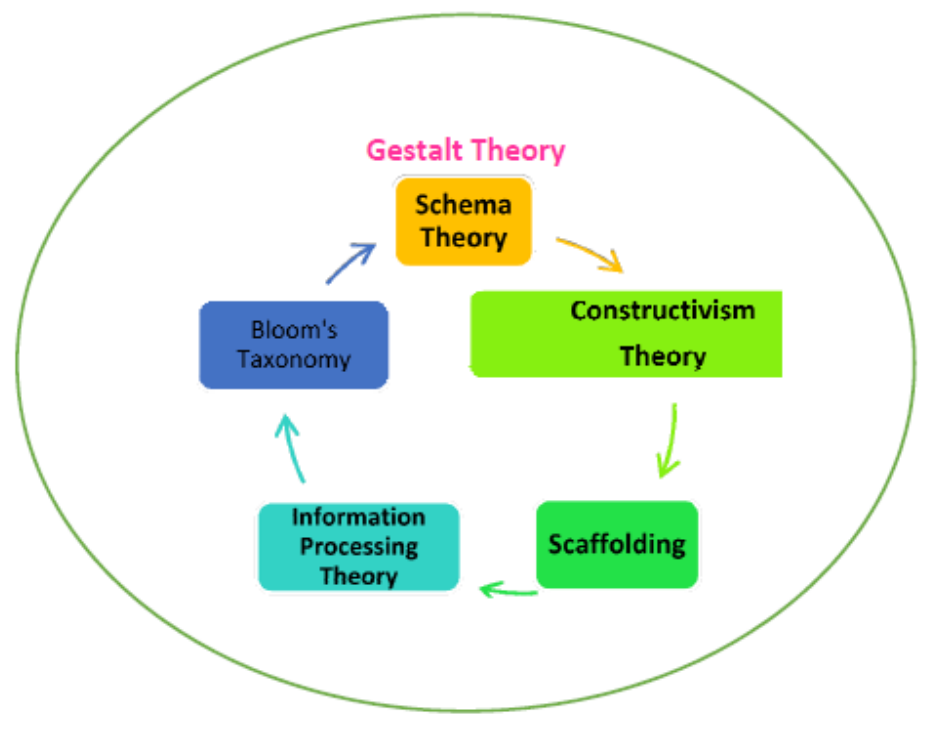

Higher Order Thinking Skills Module

Figure 1. Theoretical framework of the study

Gestalt theory holds that individuals use insight and their prior experiences before engaging in thinking (Cook, 1993). According to Gestalt theory, the critical thinking process involves problem solving which is a search to relate each aspect of a problem, by identifying the causes and effects leading to a better understanding; individuals reflect on the problem and find a better solution after weighing different types of judgements. In this 
case, the students will have to tackle the problem they face with different solutions and find alternative solutions using their critical thinking. This explains that Gestalt has an important impact on developing critical thinking skills. Not only that, Gestalt theory stimulates the students' thinking in a holistic way as it encourages the learners' memory to trace the causes and effects of a problem before stipulating a solution. This holistic perspective includes schema theory, constructivism theory and information processing theory and scaffolding that contribute to enhancing ESL learners' critical thinking skills during writing skills class. All of this thinking will then assist the students in portraying their thinking skills in the form of action words found in Bloom's Taxonomy.

Schema theory is often related to mental development. According to Fushan (2014), schema refers to a collection of knowledge often associated with a concept and it contains background knowledge of content, text structure and hierarchical organisation of the text. Using this as a guide, students need to possess and activate their previous schemata stored in their long-term memory as well as obtain new knowledge to write a good essay during the writing process. Schemata supply the necessary knowledge of phrases, content and organisation forms, which have much influence on the writing planning, revising and editing process (Fushan, 2014).

Piaget's theory of constructivism addresses how learning actually occurs, not focusing on what influences learning. According to Piaget teachers play a very important role; they act as facilitators who ensure the students learn via their own understandings. Instead of providing students with answers, teachers must challenge them by encouraging effective critical thinking. This is coherent with the research which emphasises higher order thinking skills.

In the present study, the teacher uses scaffolding to help learning. The scaffolding in this research come from the module developed based on all these learning processes. The learning process involves maximum scaffolding at the initial stage and as it progresses the scaffolding support will be reduced to allow students to do their own thinking. The teachers act as mediators who impart knowledge on how to use the writing techniques using scaffolding. The basic idea of scaffolding is that it facilitates learning and it needs to exist within a learner's Zone of Proximal Development (ZPD). The ZPD tells about the area where the learner can perform individually or the opposite, even with the help of other people. In this study, the transition from assisted learning to independent learning can happen if teachers facilitate the transition by using scaffolding techniques and gradually withdraw the small amount of assistance and slowly diminish the support once learning has taken place (Verenikina, n.d.). In the case of writing, an initial assistance is given in the form of scaffolding but as the learner progresses, independent work can be given and the teacher gradually reduces support. From this we can see how the students are able to generate ideas on their own to complete their essays after receiving some assistance and guidance on how to start writing. The scaffolding done at this stage is mostly the teacher shaping the students' way of thinking so that they do not deviate from the main objective of the writing requirement.

Similarly, Albanese (2000) quoted that information-processing theory propagated by Schmidt (1983) emphasised the importance of information processing in tapping the students' prior knowledge. Schmidt also stressed how past learning may affect the present learning experience. Students will use the knowledge that they possess from the past to propose a new solution or create a new idea during the period of thinking. Hence, students learn better when they are able to activate their existing schemata and relate the previous knowledge of the subject to understand some new knowledge. In other words, students' schemata play a major role in processing information related to the subject matter and his will exercise their thinking skills.

As for Bloom's taxonomy, the research is focused on using the higher order skills to prompt answers from the students. This research will focus on three skills, namely: application, synthesis and analysis. After inspecting the students' level via the pre-test, the researcher will introduce the writing module to the teachers. The module contains questions that focus on convergent thinking and divergent thinking. Convergent thinking focuses more on putting the different pieces of a topic together while divergent thinking emphasises breaking a topic down into its parts. In this present study, the teachers will evaluate the students' thinking skills using the verbs from Bloom's taxonomy to create students who are able to stimulate their thinking to a higher level thinking instead of using only lower order thinking. Upon receiving teacher guidance, students will be able to answer or question the writing topic with higher order thinking verbs to show the different stages of thinking throughout the writing process.

After using all the theories to construct the module, the researchers will carry out a post-test to check the module effectiveness in weak students' development especially in producing a good piece of writing. Teacher's content knowledge of higher order thinking skills for teaching writing affect their instructional strategies achieved through interaction with the students and the module used. The teacher's knowledge of using HOTS in the class 
will influence the thinking skills. The teachers will use their knowledge of the thinking skills and teach this knowledge to the students. The accomplishment of the students depends fully on the teachers' knowledge as the teachers facilitate the students' thinking with their knowledge of teaching thinking. By using the module, students will be able to master and use different types of thinking skills provided in it.

\section{Methodology}

Developing a higher order thinking skills module suitable for the targeted sample requires thorough research. Developing a module involves a variety of steps, tasks, and skills. From the four skills that constitute the learning of English language, this research will focus on the writing skill only. Having this in mind, the researchers selected the writing module because it shows a more evident result as it can be analysed on paper compared to speaking skills. Writing is also labelled as a recognised tool of communication.

As for the higher order thinking skills module, the researchers first studied the aspects of higher order thinking skill. When implementing higher order thinking skills in writing, it helps to develop critical and imaginative thinking skills. These enable students to write using a higher order thinking skill in which the students will gain the ability to write creatively and critically.

The researchers also chose writing skills because it demands a more careful organisation compared to speaking skills. Speaking skill deems to be more spontaneous unlike writing skill which is more organised as it start from development of an idea in the mind and gradually finishes on the paper. Similar to the characteristics of speaking skills, it can be expressed in both formal and informal form.

This module comes up with some strategies and activities for helping teachers to infuse higher order thinking skills to develop students' writing skills. It opens the path for teachers to explore ways of encouraging students to express themselves creatively and critically in writing.

\subsection{Module Objectives}

The module objectives are:

Objective : To

a) to assist teachers to infuse HOTS in teaching writing

b) promote the teaching of writing in English using HOTS related questions

c) develop skills for teaching effective writing through controlled and guided activities

d) enhance student's ability to use HOTS in a variety of situations

e) elicit responses from students directed to usage of higher order thinking skills

f) train students to perform unconscious critical thinking on their own

\subsubsection{Module Outcomes}

Upon completion of this module, the following outcomes will be achieved:

Outcome

a) enable teachers to infuse HOTS in teaching writing

b) give teachers a picture on how to infuse HOTS to teach writing

c) enable teachers to teach effective writing across the curriculum

d) enhance student ability to use HOTS in a variety of situations

e) develop student ability to write effectively to communicate in a variety of situations using HOTS

f) enable students to perform unconscious critical thinking on their own

\subsubsection{Time Frame}

To fully complete this module, teachers can ask students to do at least two essays from the module every week. 
If students were to do at least one essay during a double period class, it will take them around 5 months to complete the module which is approximately 20 weeks.

\subsubsection{Description of Module}

This module is designed according to the syllabus. The researchers used the Form Two syllabus to decide upon the module topics. This module ranges from both the formal and informal writing questions (refer to Table 1). Besides that the researchers also included a range of essay types: from descriptive essay, narrative essay as well as argumentative essay. For the topics chosen the researchers included a vast of area to be covered for example health, science and technology, nature and as well as self-development. Most of the topics in this module are also driven by moral values that the researcher believes to be important to instil among students.

Table 1. Topics and type of essay in the module

\begin{tabular}{|c|c|c|}
\hline & Topic & Type \\
\hline \multirow[t]{2}{*}{ Unit 1: Good times together } & Activity 1 : Vacation in Langkawi & Descriptive \\
\hline & Activity2: Unforgettable incident in a bus & Informal Letter \\
\hline \multirow[t]{2}{*}{ Unit 2: Jobs People do } & Activity 3: My ambition & Narrative \\
\hline & Activity 4:Earth is dying & Article \\
\hline \multirow[t]{2}{*}{ Unit 3: Changing Scenes } & Activity 5: Permission to Visit Forest Reserve & Formal Letter \\
\hline & Activity 6: Old Folks Home & Argumentative \\
\hline \multirow[t]{2}{*}{ Unit 4: City Extra } & Activity 7: A safer home & Report \\
\hline & Activity 8: City or Country? & Argumentative \\
\hline \multirow[t]{2}{*}{ Unit 5: The value of Friendship } & Activity 9: My best friend & Descriptive \\
\hline & Activity 10: My dog, My life saviour & Narrative \\
\hline \multirow[t]{2}{*}{ Unit 6: Day In Day Out } & Activity 11: Unity is strength & Descriptive \\
\hline & Activity 12: Social Networking & Argumentative \\
\hline \multirow[t]{2}{*}{ Unit 7: Precious Moments } & Activity 13: Depression & Argumentative \\
\hline & Activity 14: Dragon Boat festival & Descriptive \\
\hline \multirow[t]{2}{*}{ Unit 8: A healthier You } & Activity 15 : Ways to reduce air pollution & Narrative \\
\hline & Activity 16: Say No to Drugs & Narrative \\
\hline \multirow[t]{2}{*}{ Unit 9: Health is Wealth } & Activity 17: Dengue Fever & Descriptive \\
\hline & Activity 18 : Genetic Engineering & Argumentative \\
\hline \multirow[t]{2}{*}{ Unit 10: Wise choices } & Activity 19: Brother's birthday gift & Descriptive \\
\hline & Activity 20: Advantages of Television & Narrative \\
\hline
\end{tabular}

This module starts with the question from unit 1 in the Form Two text book and it goes until unit 10. For each unit, there are two questions. This module is created such that it begins with the question followed by the lesson plan. This lesson plan is a 90-minute lesson plan the teacher could use as a guideline for carrying out the lesson. The researcher also included some activities that would steer the lesson in the direction of the questions. The lesson plan created also includes questioning and group work to infuse higher order thinking skills.

\subsubsection{Module Design}

This research is based on one of the instructional designs called the ADDIE model. This model is usually used as a framework in developing educational instruments. For this case, the ADDIE model was used as assistance in developing the HOTS module. Five steps are involved in using this research design. The five phases in this design are represented by the acronym "ADDIE" which stands for Analyse, Design, Develop, Implement, and Evaluate. The order of all these phases is flexible and it does not impose an exact guideline as the name suggests.

For this research, the researcher will adopt an instructional design which goes as follows: 


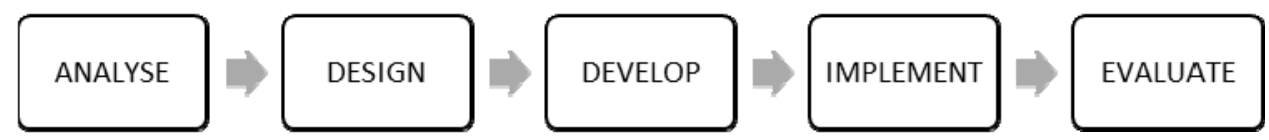

Figure 2. Module design

For the analyse stage, the researcher interviewed the teachers involved in this study and gathered information on their needs and their problems in teaching writing using HOTS to Form Two students. This data were further supported by collecting the students' past examination results. After gathering this information, the researcher then proceeded to the next stage of designing a material that could assist the teachers in teaching writing by infusing HOTS into writing lessons.

For this research the design phase is an important phase. The researcher started designing material to put in the writing module. To design materials, the researcher looked at the Form Two syllabus and consulted workbooks with PT3 format to familiarise herself with the Form Two level requirements. The researcher also looked for topics to include in the HOTS module. The topics were selected based on the text book. After listing the topics, the researcher started designing lesson plans to go along with the activities. The lesson plans were designed with the intention of implementing higher order thinking skills teaching strategies to assist teachers in using HOTS in the classroom.

During the development phase, an artist was asked to draw the pictures in the module; all the pictures are original ideas from the artist. This was done to avoid plagiarism. The researcher then started looking for Form Two teachers to validate this developed module to ensure its suitability for Form Two students. A checklist was made consisting of face validation, content validation and also construct validation. After completion of this stage was module testing.

The module was tested in two different schools. It was given to the teachers who went through it to understand its contents. The researcher then explained the module requirements including the module learning outcomes to the teachers, who then used the module during writing class for more than a month. The researcher observed the lessons to ensure that they used the module.

Next is the evaluation phase. After observing the teachers and the students, the researcher asked for feedback from the participants via interviews. For the summative assessment, the researcher did a post-test to check the module effectiveness. Before implementing the module, the researcher gave a pre-test to the students.

\subsubsection{Module Validity}

A few procedures were used to measure the module validity. This research looked into the face validity, content validity and construct validity of the instrument. Face validity refers to a subjective assessment done by researchers to identify the relevance of instruments in the measuring item to be relevant, reasonable and clear (Oluwatayo, 2012). For this research it refers to how relevant is the higher order thinking skill module in helping the students use HOTS while writing. Sangoseni et al. (2013) stated that content validity refers to whether the content of the items measured in the instrument are representative and sufficient in evaluating a situation. For this research, the content validity refers to the activities and the lesson plans in the module. On the other hand, construct validity is the degree to which an instrument evaluates what it is measuring (Brown, 1996, p. 231).

Therefore, for this research, the researcher made a checklist inclusive of the face validity, construct validity as well as the content validity. To check these validity, the researcher selected a school and asked the assistance of three Form Two teachers to evaluate the module. The teachers also tested out the module to ensure that its instruments were suitable for Form Two students. Each teacher was given a month to test and validate the instrument.

\subsubsection{Assessment}

After each question in the module, the teacher is required to assess the student's answer. The answer scheme is also provided in the module. Each question prepared in the module is made into an assessment activity which is for self-development and is not required for submission to anybody. The module goal is to develop students' thinking skills, not to test them for examination. Assessment is also meant to encourage the teacher to think about and devise some innovative teaching practices that could make their teaching more exciting and relevant to students. All assessments are to be completed at the end of every unit. 


\subsection{Research Design}

This study is classified as qualitative research that adopts a multiple exploratory case study method for several reasons. A case study research design was carried out in the second phase for 10 weeks at two different schools in Johor and Kedah. Case study design was adopted because it helped to provide an in-depth understanding of the chosen samples and the context. Case study research is a research used in education to study the processes, development and underlying forces of practice (Merriam, 1988). Choosing a good case study is essential to explore and gain an in-depth understanding of a particular subject. A case is seen as a bounded system that particularly refers to a specific group or situation or environment (George et al., 2005; Merriam, 1988). This is similar to what Cohen, Manion, and Morrison (2012) stated, that a case study is seen as a bounded system providing a unique example of real people in real situations, enabling readers to understand ideas more clearly than simply by presenting them with abstract theories or principles.

\subsubsection{Participants}

Participants were selected based on snowball sampling. The sampling frame is a representation of all the elements in the population from which the sample is drawn. In this research, researchers have selected two ESL teachers and 45 students from Kedah and Johor.

The samples of this study are two ESL teachers and forty-five ESL learners from two secondary schools from different zones that would represent different states. These teachers are English teachers with 5 to 10 years of experience teaching English. They received training as English teachers at teacher training institutes and universities where they took the English language as their major. These teachers are also English option teachers who have been attending regular workshops and courses to upgrade themselves professionally and linguistically. The participants of this research are Form Two students of the same lower secondary forms. They are with mixed abilities but the majority of them are weak in English since they are from rural areas. The majority of them have little exposure to English language. These Form Two students were chosen because they are very weak in English and needed more attention in English lessons. Most of them performed poorly in the English language paper and this was deduced from their Midterm and Year End examination results.

\subsubsection{Data Collection}

Three different types of techniques (data analysis, observation and interview) are used to carry out this research. Based on these techniques the researcher came out with instruments that would be used to represent these techniques. The instruments for this study are pre-test, post-test, video recording, observation and structured interview.

Before conducting the research, the researchers tested two lessons from the module, the interview questions on one teacher and two students respectively. The researchers also carried out the pre-test and post-test on weak Form two students of similar ability as the research participants. The results from this pilot study were taken into consideration and corrections were made to the module based on them.

\subsection{Observation}

Observations enable the researcher to describe existing situations providing a "written photograph" of the situation under study (Erlandson, Harris, Skipper, \& Allen, 2013). Carrying out an observation is important for this research as it allows the researchers to observe usage of the HOTS module for teaching writing in a class. Besides observing the teachers, the researcher observed how the students react to the module using HOTS for teaching writing. For this study, the researchers observed ten lessons carried out by the two ESL teachers using the module provided. The teachers were observed by the researchers using an observational checklist. The checklist focused on HOTS implementation in the specific lesson; it consisted of 34 descriptors and nine subtopics. The themes were selected based on the HOTS aspects. For example, the themes were reasoning, connecting concepts, inferring, problem solving strategies, questioning analysing, synthesising and evaluating.

\subsection{Interview}

Interview involves asking questions and getting answers from the subjects and researchers can use the interview to collect valid and reliable data vital to the research questions and objectives of the study, as it can elicit more information, and the interviewees' knowledge on the issue of research (Cohen et al., 2012). For this study the researchers interviewed two ESL teachers. In-depth interviews were chosen because they provide much more detailed information than what possible through other data collection methods. The teachers' interview consisted of 27 questions. The first part of the interview is to know about the teachers' way of teaching, their viewpoint of teaching HOTS, ways to assess HOTS and the teaching strategies used. This was then followed by more detailed questions asking teachers about their perceptions on HOTS, the benefits of HOTS while the third section was on 
the module strengths and weaknesses as well as suggestions for improving it.

Eight students were selected from each class to be interviewed. The interview responses were divided into different themes and analysed. Students were interviewed to gather useful information related to this research such as their problems in writing, usage of HOTS and their opinions about the module.

\subsection{Document Analysis}

According to Weber (1990), document analysis is the systematic examination of instructional documents such as syllabi, assignments, lecture notes, and course evaluation results. This is then used to identify instructional needs and challenges and describe an instructional activity. The tests given to the students were divided into the pre-test and the post-test. Before the intervention, a pre-test was administered to record the participants' present writing ability. At the end of the research, which is after usage of the HOTS module, a post-test was administered to ascertain the students' writing achievement. For the pre-test and post-test, the researchers applied this instrument to find out the effectiveness of implementing HOTS questions in improving writing skills. The pre-test and post-test questions were adapted from a range of PT3 question papers. The students were expected to write an essay on pollution. For each sample, the test was conducted individually to ensure that student worked alone without any help. This enabled them to write based on their true ability. After the teaching sessions, students were expected to take a post-test to identify their writing performance after exposure to HOTS in writing. This was to assess what they have learned and to see their progress. Two experienced PT3 teachers marked the collected scripts using the report writing marking criteria. The two teachers marked the scripts independently and assigned scores. Then, the pre-test and post-test scores were analysed quantitatively using statistical analysis.

\subsection{Data Analysis}

According to Richard and Lockhart (1990), analysing qualitative data is an important process in research as it allows one to make sense of the data collected. The data were organised upon collection. The method of organising data depends on the type of research done, research strategy as well as the data collection technique. The next stage would be data description. After organising the data, numerous aspects of the study including the individuals being studied, the purpose of the lessons carried out as well as the viewpoints of participants and the effects of any activities on the participants and students were investigated. The third and final phase of analysis is interpretation which provides an explanation of the findings and answers the research questions. Therefore several types of data analysis can be carried out for this research. Thematic analysis was used to organise the ideas developed from the data.

Thematic analysis was used to analyse the interview transcriptions to determine the HOTS module effectiveness. After identifying the themes, the researchers looked at the relationship between the themes. The codes from the data collection were then further organised under sub themes and sub categories in which they act as a tool to identify meaning connections and relationships. The coding process for the transcripts can be best explained with the three steps described by Neuman (2011), namely: open coding, axial coding and selective coding. Open coding is basically the naming of parts of meaning from either the field notes or transcripts coherent with the research topic. Axial coding is carried out by reviewing and examining the initial codes identified during the open coding. During this stage also, categories and patterns are identified and organised in terms of causality, context and coherence. Last but not least is selective coding involving selective scanning of all codes that will be identified for comparison or contrast to the research question.

\section{Results and Discussion}

The results of using the higher order thinking skills module can be seen in two forms which are the detailed classroom observation and the results from the pre-test and post-test from both the schools. From the 10 classroom observations, it can be seen that the lessons from both the schools share the same themes. Using this, the researcher analysed the classroom observations using thematic analysis. The themes shared by the 10 observations are similar to the strategies used in the teaching of higher order thinking skills. Using the assistance of the module, the teachers used the following strategies to help them teach HOTS better.

One of the similar themes found is the use of graphic organisers to teach students higher order thinking skills. Graphic organiser refers to the use of a diagram to record the learners' thinking in a visual map. Graphic organiser is known to be one of the effective learning strategies for encouraging higher order thinking skills. Graphic organisers are said to be linked with HOTS because they promote reasoning, comparing and contrasting ideas, listing, making connections which are some of the verbs found in Bloom's Taxonomy. The graphic organisers used for this research are also known as i-THINK map that can be downloaded by the teachers from the web. Graphic organiser is one of the ways to draw out ideas from students. The students used more than one 
type of graphic organiser. They were able to use a listing mind map, a process mind map, a bubble mind map and also a disc shape mind map. For example, graphic organiser was used by the teacher for one of the activities relating information to main themes and ideas. After asking the students to discuss the ideas in their respective groups, the teacher then collected their ideas in a bigger mind map (Figure 3).

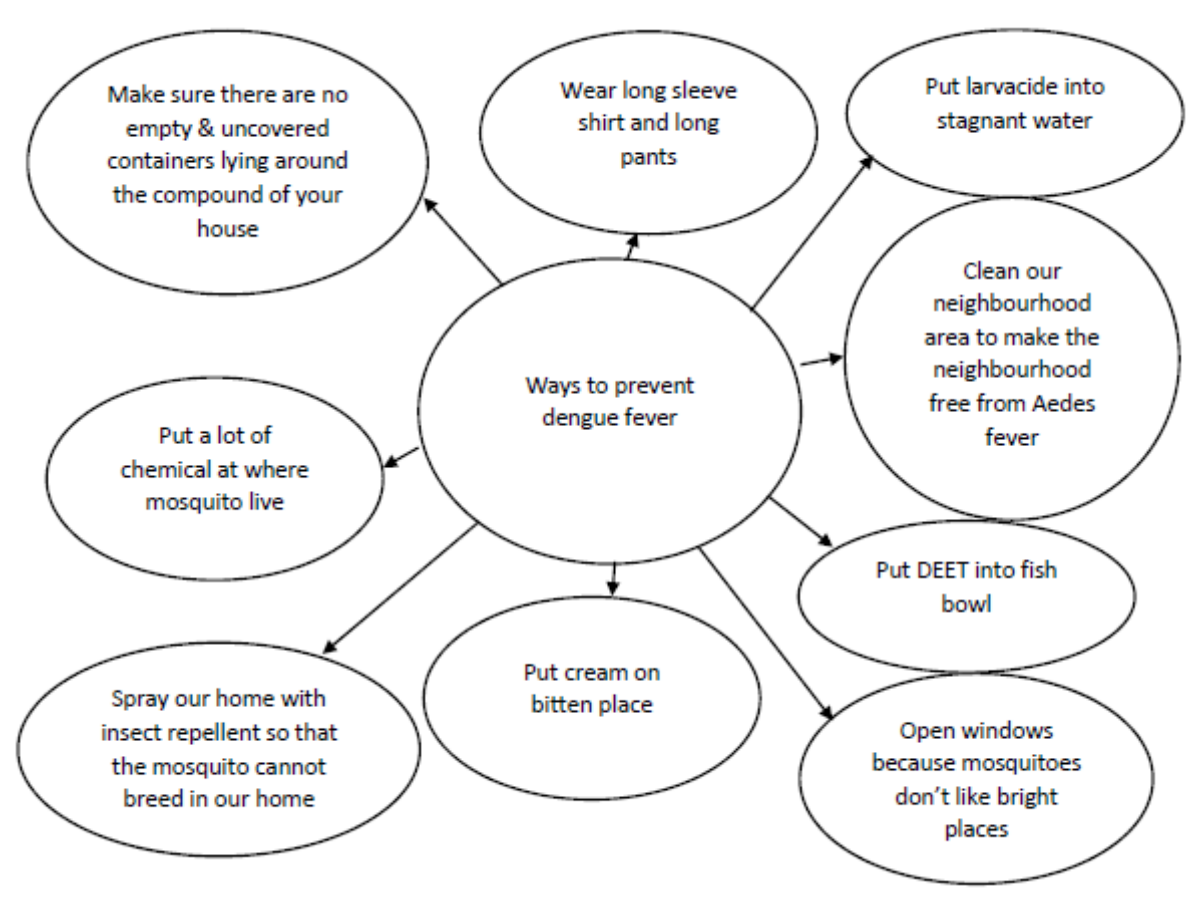

Figure 3. Graphic organiser

Another strategy the teachers used was questioning. Redfield and Rousseau (1981) conducted a meta-analysis study and found a positive relationship between questioning during instruction and student's factual recall and application of thinking skills. Questions are often classified by the level of cognitive requirement utilised to answer them. The questioning used depends on the type of answer that we want to hear. Some of the questions teachers used were open ended question, close ended questions, recall and process questions and also funnelling. Open ended questions open up room for explanation. One type of questioning skill closely linked to higher order thinking skills is funnelling. The teacher does this a lot so that the students can think the way the teacher wants them to think. After asking a question and upon receiving an answer the teacher will further question to get more insight into an idea. Throughout the lessons, the teacher kept changing from one type of questioning to another type depending on the type of response required and also the purpose of questioning. The teachers usually began their lessons with a close ended question and then slowly move to an open ended type of question after familiarising students with the topic.

One of the components of higher order thinking skills is comparing and contrasting ideas. Comparing and contrasting ideas for the activities in the module allowed the students to identify the different perspectives among their peers and select a suitable answer after evaluating all the possible consequences. Kagan (2003) supports this statement when he reviewed the process of making students process a piece of information is by having the student understand the information first and this will then allow the student to categorise, analyse, synthesise, and then apply the information. In the current study, the students could identify the relationship between two idea presented on the board. The teacher listed problems and solutions based on their responses. Students were able to identify the relationship between the problems and were able to come up with a solution and continued elaborating their idea after connecting the relationship of two ideas. They were able to apprehend that each problem had a solution. For instance in one of the activities on global warming, when there is too much deforestation that it causes global warming, the solution was either to plant more trees or have the law enforced. When the students were able to connect these concepts they were able to understand better.

Besides that, the teachers also asked cause and effect question to her students. Briner (1999) mentioned that the 
teacher acts as a facilitator, stimulates and provokes the student's critical thinking and analysis skills throughout the learning process. Cause and effect questions are also one of the techniques of infusing higher order thinking skills into writing lessons. Such questions allow students to think as they elaborate more on a situation. Cause and effect allows the students to describe and explain the causal relationships between actions or events from the module developed. For students to practice thinking, they need to be active thinkers by asking questions and applying metacognitive strategies (Briner, 1999). In this case, the students were able to define a problem or a dilemma and either identify its solution in the text or suggest a possible solution. This was captured when the module activities required students to answer a problem solving question very closely related to their daily situation.

Fisher (2003) mentioned that everyone has equal rights to be educated. He then stressed on one of the main criteria of education which is to teach students to think critically, creatively and effectively. Therefore, one of the things teachers often do when the students cannot understand is by creating mind movies or in other words providing examples. The teachers did this to ensure that the students understand clearly and also to ensure their responses follow the directed activity. One way for teachers to check on student understanding is by making students give examples to a situation. In one instance, the explanation that the teacher provided shows that the students were unable to elaborate the points further until the teacher told them the meaning of voluntary work. Giving example also prompts students' thinking cap.

Teacher: How do you save money by doing work voluntarily?

Student: (they do not understand the word volunteer and give her a blank stare)

Teacher: when you do volunteering work, you help people for free

Students: Oh...

Student: Don't take money, help for free

Students: (start writing)

Reasoning helps students to think logically and sensibly. Fisher (2003, p. 8) claims that teaching thinking and reasoning is the backbone in ensuring good standards among students as it is the most basic skill of the curriculum. This can be seen in this activity via two channels. First is by looking at the students' answers from the mind map. The students wrote the answers in a very distinct manner. Reasoning also helps teachers to receive more feedback on a response to see whether the students understand an idea well. In one of the module activities, the teacher questioned the students' answer from the graphic organiser drawn by them. The teacher did so to allow students to elaborate more on their answer by using why-how questions.

Teacher: How do you neglect your studies?

Student: Don't do homework or revision

Student: Busy chatting with friends

Teacher: Okay what about lazy?

Student: Don't help mother

Teacher: What do you mean don't help mother?

Student: Always play with phone don't help mother with housework

Teacher: Okay next. How to have eye problem?

Student: Play too much game cannot sleep

Student: Look at the phone too long

Teacher: Okay good

These are the examples of situations where students are able to provide suitable reasoning for their own ideas. During these activities it can be seen that students were serious with their responses and were able to provide answers related to the question. For instance, in this case the teacher moved to the next question although most of the answers given by the students were short yet precise. A successful reasoning is when a good conclusion is achieved. In this case, the teacher was satisfied with the reasoning the students provided.

One of the teaching strategies that could help teachers to use HOTS in their lesson is by asking students to do inferring. In this module inferring refers to the teacher acting to make inference by giving students real-world examples. According to Sherman (2013), when students relate their learning to their own life experiences, their 
understanding and memory capabilities will increase. In one of the lessons, when the teacher asked the students to write down some incidents that they cannot forget some of them wrote down their unforgettable memories and this triggered the teacher to ask the students "what if" questions. Based on the students' responses, the teacher questioned the students if their initial response would really get them out of the problem. In this case when the teacher asked the students what they will do if they encountered a problem where they cannot go home, some of the students responded that they would walk back home and some answered that they will scream. Both these responses are not wrong but will not solve the actual problem and one is not applicable to those staying far from school. The students then made an inference from their teacher's feedback and gave three new answers that made more sense and could get the students home eventually.

One of the teachers also used paraphrasing to assist the students. In one of the activities, the teacher made the students paraphrase one of their responses to check the authenticity of the response.

Teacher: What do you mean by negative impact?

Student: It means thing that are not good for you.

Paraphrasing here shows that the teacher wanted to check upon the students' understanding of their initial response. This is also one of the ways of ensuring that the entire class in able to apprehend the meaning of the word from the viewpoint of their peers.

\subsection{Pre-test and Post-test Results}

Test results were obtained from the pre-test and post-test administered in both the schools. The pre-test and the post-test were similar for both schools. Both the compositions are rewarded with 30 marks each, in line with the PT3 format used in schools and the Malaysian national examination.

Table 2. Pre-Test and Post-Test Scores for school SMKSP (Kedah)

\begin{tabular}{lll}
\hline Name & Pre Test (30 marks) & Post Test (30 marks) \\
\hline A & 2 & 5 \\
B & 2 & 4 \\
C & 3 & 6 \\
D & 5 & 7 \\
E & 4 & 7 \\
F & 5 & 7 \\
G & 7 & 8 \\
H & 5 & 6 \\
I & 5 & 6 \\
J & 6 & 7 \\
K & 5 & 6 \\
L & 1 & 1 \\
M & 1 & 1 \\
N & 2 & 3 \\
O & 2 & 3 \\
P & 3 & 7 \\
Sum & 58 & 84 \\
Mean & 3.625 & 5.25 \\
Standard deviation(s) & 1.874 & 2.206 \\
Variance $\left(s^{2}\right)$ & 3.45 & 4.87 \\
Standard Error of the Mean $\left(\mathrm{SE}_{\bar{x}}\right)$ & 0.464 & 0.552 \\
\hline
\end{tabular}


Table 3. Paired Sample Pre-test and Post-Test SMKSP

\begin{tabular}{lllllll}
\hline $\begin{array}{l}\text { Mean of pre-test } \\
\text { minus Post-test }\end{array}$ & $\begin{array}{l}95 \% \text { confidence interval of } t \text { - } \\
\text { this difference } \\
\text { Lower }\end{array}$ & Higher & & $\begin{array}{l}\text { Standard error of } \\
\text { difference }\end{array}$ & $\begin{array}{l}\text { The two-tailed } p \\
\text { value }\end{array}$ \\
\hline-1.63 & -2.21 & -1.01 & 5.6647 & 15 & .0287 & 0.0001 \\
\hline
\end{tabular}

A paired-samples $t$-test was conducted to see the difference between the mean scores of the experimental group on pre-test and post-test. A significant difference existed between the mean scores of the experimental group on pre-test and post-test from pre-test $(M=3.625, S D=1.874)$ to post-test $(M=5.25, S D=2.206, t(15=-5.6647)$, $p<0.0001)$. Thus, we can conclude that there was a large effect between the mean scores on school SMKSP on pre-test and post-test. The sig (two-tailed), $p=0.000<p=0.001$ with the degree of freedom, $\mathrm{df}=15$. The $p$ value was smaller than alpha 0.001 which meant that there is positive difference in the mean scores. As a result, we can conclude that there was a significant difference between the mean scores of SMKSP on pre-test and post-test.

Table 4. Pre-Test and Post-Test scores for School SMKPG (Johor)

\begin{tabular}{lll}
\hline Name & Pre Test & Post Test \\
\hline A & 9 & 12 \\
B & 12 & 17 \\
C & 8 & 10 \\
D & 10 & 11 \\
E & 10 & 12 \\
F & 10 & 18 \\
G & 11 & 13 \\
H & 7 & 9 \\
I & 8 & 9 \\
J & 11 & 14 \\
K & 9 & 12 \\
L & 10 & 12 \\
M & 10 & 18 \\
N & 8 & 9 \\
O & 11 & 13 \\
P & 11 & 12 \\
Q & 12 & 13 \\
R & 10 & 11 \\
S & 7 & 9 \\
T & 8 & 12 \\
U & 7 & 12 \\
V & 15 & 20 \\
W & 11 & 12 \\
X & 15 & - \\
Y & 11 & 18 \\
Z & 15 & \\
A1 & 12 & \\
\hline & & 9 \\
\hline
\end{tabular}




\begin{tabular}{lll}
\hline B1 & 9 & - \\
$\mathrm{C} 1$ & 8 & - \\
Sum & 290 & 377 \\
Mean & 10 & 13 \\
Standard deviation(s) & 2.053 & 2.964 \\
Variance(s & & 8.786 \\
Standard Error of the Mean & 0.381 & 0.550 \\
$\left(\mathrm{SE}_{\overline{\mathrm{x}}}\right)$ & & \\
\hline
\end{tabular}

Table 5. Paired sample Test Pre-test and Post-test SMKPG

\begin{tabular}{lllllll}
\hline $\begin{array}{l}\text { Mean of pre-test } \\
\text { minus Post-test }\end{array}$ & $\begin{array}{l}95 \% \text { confidence interval of } t \text { - } \\
\text { this difference } \\
\text { Lower }\end{array}$ & Higher & value & $\begin{array}{l}\text { Standard error of } \\
\text { difference }\end{array}$ & $\begin{array}{l}\text { The two-tailed } p \\
\text { value }\end{array}$ \\
\hline-3.00 & -3.81 & -2.19 & 7.6158 & 28 & .0394 & 0.0001 \\
\hline
\end{tabular}

A paired-samples $t$-test was conducted to see the difference between the mean scores of the experimental group on pre-test and post-test for the second school. A significant difference was found between the mean scores of the experimental group on pre-test and post-test from pre-test $(M=10, S D=2.053)$ to post-test $(M=13, S D=$ $2.964, t(28=-7.6158), p<0.0001)$. Thus, we can conclude that there was a large effect between the mean scores on school SMKPG on pre-test and post-test. The sig (two-tailed), $p=0.000<p=0.001$ with the degree of freedom, $\mathrm{df}=28$. The $p$ value was smaller than alpha 0.001 which meant that there was a significant difference in the mean scores. As a result, we can conclude that there was a significant difference between the mean scores of SMKPG on pre-test and post-test.

A few aspects have not been covered in this study which results in the limitation of its findings. Firstly, the subjects of the study are limited to two schools only, one each in Johor and Kedah. The researcher found only two schools to study and two teachers who are of different background and they teach in different states. The findings of this study were based on the responses and performances of the teachers and students during the selected learning units only, without considering those in other lessons. Thus, the findings do not reflect the outcomes of the whole learning unit. The focus of the study is to look at the process of teaching writing through the HOTS module developed in a Form Two classroom context. Thus, it does not look at any specific aspects of English language nor can any correlations or links be made to particular language schools.

\section{Conclusion}

This study finds that the higher order thinking skills used by the teachers in the study had positive effect on student learning using the HOTS module. The students enjoyed the techniques and commented on how they helped them to write better. Moreover, analysis of the post- test scores in comparison with the pre-tests for both schools shows a significant difference between mean scores for writing achievement. Analysis of the students' responses to the classroom observations seems to indicate that almost half of the students' weaknesses were their problems in applying HOTS in writing. Analysis of interview data shows that the students preferred the HOTS module as it assists them in writing. Among the reasons cited were that they work in groups and get support from their peers. They were also keen to be drawing mind maps to help them get more ideas.

The interviews also reveal that the HOTS module enabled them to draw out more ideas from the pictures and helping words so that they can improve on their writing. Using the HOTS module in learning can encourage social interaction which preceded learning, as they were exposed to group work. The findings of the study reveal that the students were positive about adopting the higher order thinking skills techniques suggested by their teachers for improving their writing performance. The scaffolding given including questioning, reasoning, comparing and contrasting helped the students not only in learning but in self-regulation at the end of the learning process.

Teachers are expected to benefit from this study and become more aware of their role as facilitators of learning and their responsibility in infusing higher order thinking to help them move up to a higher level. It is also proven that assistance and guidance can help students in their learning especially in writing. Being able to generate ideas 
to write is not easy especially among weak learners. Tayler (2001) argues that developing a learner's thinking involves the context and how adults help learners to learn.

Therefore, it is time for teachers and educators to implement a new technique in teaching writing by integrating higher order thinking skills in their lesson. This study clearly shows that it is necessary to conduct a more extensive research on using HOTS and document the findings for helping future teachers and students improve writing performance among weak students especially. If more research is done on using HOTS, the effects will be evident, resulting in a more appropriate teaching strategy being used for enhancing the English language competency and proficiency now waning at an alarming rate among Malaysian students.

It can be concluded that, overall, the students had a positive view of the HOTS module in assisting them in writing. This study can also act as a guideline for teachers especially the lower form teachers. The findings are more suitable to be applied on weak and intermediate level students who are about to embark on the writing process. Teachers might need to modify the questions and the approach to suit their students' proficiency level. The findings suggest that the HOTS module used in this study can enhance student learning as it offers an interesting approach in learning how to write better using HOTS.

\section{Acknowledgement}

We acknowledge with great appreciation the kind gesture of the Malaysian Ministry of Higher Education for providing us the Fundamental Research Grant Scheme (Coded: FRGS/KPT 2016-0068-107-02: FRGS/1/2016/SS109/UPSI/02/15). Equally, we would like to express our gratitude to all the participating teachers for their willingness to be observed and to share their classroom practices.

\section{References}

Albanese, M. A. (2000). Problem-based learning: A review of literature on its outcomes and implementation issues. Academic Medicine, 68(1), 52-81. https://doi.org/10.1097/00001888-199301000-00012

Briner, M. (1999). Learning theories. Denver, CO: University of Colorado.

Brown, S. R. (1996). Q Methodology and qualitative research. Qualitative Health Research, 6(4), 561-567. https://doi.org/10.1177/104973239600600408

Cohen, L., Manion, L., \& Morrison, M. (2012). Research methods in education (7th ed). New York, NY: Routledge.

Cook, D. (1993, October). Behaviourism evolves. Education Technology, 62-77.

Erlandson, E. A., Harris, L., Skipper, B., \& Allen, S. D. (2013). Doing naturalistic inquiry: A guide to methods. Newbury Park, CA: Sage

Fisher, R. (2003). Teaching thinking: Philosophical enquiry in the classroom (2nd ed.). New York, NY: Continuum.

Fushan, S. (2014, July). The Application of Schema Theory in Teaching College English Writing. Theory and Practice in Language Studies, 4(7), 1476-1482.

George, A. L., \& Bennett, A. (2005). Case studies and theory development in the social sciences (4th ed.). Cambridge, MA: MIT Press.

Hashim, R. (2003). Malaysian teachers' attitudes, competencies and practices in the teaching of teaching. Intellectual Discourse, 11(1), 27-50.

Kagan, S. (2003). Kagan Structures for Thinking Skills.

Merriam, S. B. (1988). Qualitative research and case study applications in education (2nd ed.). San Francisco, CA: Jossey-Bass.

Neuman, W. L. (2011). Social research methods: Qualitative and quantitative approaches (7th ed.). Boston, MA: Pearson.

Oluwatayo, J. (2012). Validity and reliability issues in educational research. Journal of Educational and Social Research, 2, 391-400.

Rajendran, N. (1999). Teaching Higher Order Thinking Skills in language classrooms: The need for transformation of teaching practice. (Ph.D dissertation, Michigan State University).

Redfield, D., \& Rousseau, E. (1981). A meta-analysis of experimental research on teacher questioning behaviour. Review of Educational Research, 51(2), 237-245. https://doi.org/10.3102/00346543051002237 
Richard, J. C., \& Lockhart, C. (1990). Teacher development through peer observation.

Sangoseni, O., Hellman, M., \& Hill, C. (2013). Development and validation of a Questionnaire to Assess the Effect of Online Learning on Behaviors, Attitudes, and Clinical Practices of Physical Therapists in the United States Regarding Evidence-based Clinical Practice. The Internet Journal of Allied Health Sciences and Practice, 11(2), 1-13.

Schmidt, R. (1983). Interaction, acculturation, and the acquisition of communicative competence. In N. Wilson, \& E. Judd (Eds.), Sociolinguistics and language acquisition (pp. 137-174). Rowley, MA: Newbury House.

Sherman, K. (2013). How social media changes our thinking and learning. Central Piedmont Community College.

Siti, N. B. M. (2016). Teachers' perception on the integration of HOTS in language teaching. International Journal of Technical Research and Applications, 15, 561-575.

Tajularipin, S., Vickneswary, M., Diwiyah, M., Raidah, H., \& Suzieleez, S. A. R. (2017). Implementation of Higher Order Thinking Skills in teaching of Science: A case study in Malaysia. International Research Journal of Education and Sciences (IRJES), 1(1).

Tanujaya, B. (2016). Development of an Instrument to Measure Higher Order Thinking Skills in Senior High School Mathematics Instruction. (Department of Mathematics Education, University of Papua).

Tayler, C. (2001). Australian early childhood milieu: Teacher challenges in promoting children's language and thinking European Early Childhood Education Research Journal, 9(1), 41-56.

Weber, R. P. (1990). Basic content analysis (2nd ed.). Newbury Park, CA: Sage. https://doi.org/10.4135/9781412983488

Verenikina, I. (n.d.). Understanding scaffolding and the ZPD in educational research.

\section{Copyrights}

Copyright for this article is retained by the author(s), with first publication rights granted to the journal.

This is an open-access article distributed under the terms and conditions of the Creative Commons Attribution license (http://creativecommons.org/licenses/by/4.0/). 